\title{
Apologia, Image Repair and Rhetoric in the Defence of Electoral Defeat
}

\author{
Kwabena Sarfo Sarfo-Kantankah*
}

Department of English, Faculty of Arts, College of Humanities and Legal Studies, University of Cape Coast

Corresponding Author: Kwabena Sarfo Sarfo-Kantankah, E-mail: esarfo@ucc.edu.gh

\section{ARTICLE INFO}

Article history

Received: January 12, 2019

Accepted: April 04, 2019

Published: June 30, 2019

Volume: 10 Issue: 3

Advance access: May 2019

Conflicts of interest: None

Funding: None

Key words:

Apologia,

Image Repair,

Rhetoric,

Defence,

Electoral Defeat

\begin{abstract}
Using the concepts of apologia, image repair and rhetoric, this paper examines the strategies employed by a former president of the Republic of Ghana to simultaneously maintain his reputation after losing the 2016 Ghanaian general elections and campaign for re-lection as the standard bearer of his party. The paper finds that the former president did not accept responsibility for the electoral loss, but used several indirect ways to deny responsibility for the defeat. He employed bolstering, accusation/attack, playing the victim, throwing a challenge and the God's will factor as defence strategies in order to repair his image. He exploited the Aristotelian appeals of logos, ethos and pathos to boost his persuasion. In doing so, he deployed several rhetorical tools such as metaphor, allusion, rhetorical questions and parallelism to enhance the expression of the defence strategies. The analysis reveals that, as noted in the literature, some of the image repair strategies espoused by Benoit $(1995,2015)$, for example, outright denial and mortification, hardly apply to political contexts - the former President's defence was indirectly expressed. Thus, the paper concludes that combining the concepts of apologia, image repair and rhetoric in the analysis of political discourse can illuminate political discourse analysis. The paper has implications for communicating defence, reputation repair and political rhetoric.
\end{abstract}

\section{INTRODUCTION}

In December 2016, Ghana saw one of the most keenly contested presidential and parliamentary elections in Ghana's fourth republican democracy (since December 1992). It was the first time an incumbent president and government lost an election in the first round of polls. The defeat was blamed on the then President and presidential candidate John Mahama of the National Democratic Congress (NDC). The Ghanaian media were inundated with reasons why the NDC, led by President Mahama, lost the elections, with a large number of people, including his own political party members accusing him for the electoral defeat. The attacks and accusations against Mahama became more intense when he declared his intention to re-contest the NDC's standard bearer race. Prior to Mahama declaring his intention to contest again, the NDC had organised several Unity Walks in all the ten regions of Ghana. As noted by President Mahama, "the purpose of this walk is a solidarity walk; it is a unity walk; it is to raise the morale of our party; it is to engage our party members so that they are conscious of the re-organization that is taking place" (NDC Unity Walk, Wa, Upper-West region, $7^{\text {th }}$ April, 2018). At each of the Unity Walks, John Mahama gave a speech in which he sought to give reasons why the NDC lost the 2016 elections and how they should prepare and bounce back to contest and win the 2020 elections. Each of the speeches can be considered as multi-purposed, since Mahama sought to defend himself, repair his damaged reputation and campaign for re-election as the NDC's standard bearer for the 2020 elections. Thus, a close examination of the speeches brings to bear how the concepts of apologia, image repair and rhetoric come into play. Based on these concepts, this paper examines seven of Mahama's speeches in order to explore how Mahama tried to defend himself, regain his reputation and prepare the grounds for his comeback. Combining the three concepts is illuminating because, notwithstanding the copious scholarly attention on apologia, political discourse, political communication and image repair (cf. Achter, 2000; Roland \& Jerome, 2004; Boyer, 2011), there is hardly any study that concurrently deploys the concepts of apologia, image repair and rhetoric to analyse political speeches. This deprives us of a comprehensive understanding of how politicians simultaneously engage in defence, image repair and campaign rhetoric. Considering that the world has become a global village with so much socio-political interconnectedness, studying political discourse in contexts such as Ghana will help expound global debates on the ways in which politicians manage their reputation in the face of scandals and failures. This is because what is defensible, reputable, as, for example, admission of culpability, denial and evasion of responsibility, differs from society to society, since social values and morals are culture specific. 


\section{APOLOGIA, IMAGE REPAIR AND RHETORICAL THEORIES}

Apologia is defined as "the speech of self-defense" initiated by an attack on a person's character that calls for defence, in which he/she "attempts to reconcile a derogatory charge with a favourable view of his character" (Ware \& Linkuel, 1973 , p. 274, 275). Apologia is said to have originated from ancient Greek rhetoric. As noted by Towner (2009, p. 437):

The term apologia has been traced back to the ancient Greek root word apologos, meaning “a story" (Partridge, 1977, p. 347). Tavuchis (1991) explained that it first appears in the Oxford English Dictionary as apoloyiaapo, meaning "away," and loyia, meaning "speaking" and is defined as a speech in defense or as a vindication of a person (p. 15). In ancient Greece, citizens regarded such a defense as an important genre of rhetoric. Plato, Isocrates, and Aristotle characterized apologia as a specific genre in which an orator defends himself or his actions against an accusation (Ryan, 1982).

Thus, apologia is a defensive rhetoric, and defence is one of the means of maintaining reputation and how the defence is communicated is essential for the success, or otherwise, of repairing one's image. In fact, Kruse (1981, p. 279) includes image repair in the definition of apologia, viz: a "public discourse produced whenever a prominent person attempts to repair his character if it has been directly or indirectly damaged". Benoit's (1995, 1997, 2000, 2004, 2015) image repair theory actually draws largely on the principles of apologia. For example, the image repair theory involves the features of apologia such as "denial", "bolstering", "differentiation" and "transcendence" (Ware \& Linkuel, 1973, p. 275). From its classical concentration on legal contexts (Boyer, 2011), apologia has been applied to corporate crisis communication or organisational apologia (cf. Roland \& Jerome, 2004), and political contexts, as a result of political scandals in contemporary politics (cf. Achter, 2000). Achter (2000) attributes the increased studies on political apologia to the confluence of changes in the media coverage of political campaigns, and the ubiquity of political scandals complicates traditional studies of apologia.

Defined as the "reputation of a person (or group, or organization) held by the audience, shaped by the words and actions of that person, as well as by the discourse and behaviour of other relevant actors" (Benoit, 1997, p. 251), image (or face, or reputation) is essential for maintaining one's status and respect in society. When people feel that their image or reputation has been threatened or damaged, they find several ways of repairing or restoring that image. Benoit's (1995, 1997, 2000, 2004, 2015 ) image repair theory is a set of principles designed to examine and for understanding the maintenance of reputation when it is damaged or threatened. It is an analytic framework for crisis situations. It comprises the following typology of strategies (see Benoit, 1995, 2015; Len-Rios \& Benoit, 2004):

i. Denial, which involves an outright denial or shifting blame such that responsibility is assigned to someone else;

ii. Evasion of responsibility: consisting of claim to provocation, defeasiblity (claiming a lack of control over the act), accident (claiming that the act happened by accident), and good intention (offender claiming that he had good intentions for the act). All these help to reduce responsibility for the offensive act.

iii. Reducing offensiveness of the event, which involves reducing "the degree of ill feeling experienced by the audience" (Benoit, 1995, p. 77). This strategy has sub-categories, comprising bolstering (talking about one's positives to offset the offensiveness of the act), minimising negative feelings (claiming that the effects of the act were exaggerated), differentiation (comparing the offence to other more serious offences), transcendence (placing the act in a broader, often moral context, to justify a claim of "the end justifies the means" (Len-Rios \& Benoit, 2004, p. 97)), attacking the accuser, and compensation (offering reparation or restitution);

iv. Corrective action, such as restoring the state of affairs and forbearance; and

v. Mortification, a straightforward apology.

From an initial study of corporate crisis situations and image restoration/repair (Benoit, 1995, 1997), the theory has been used to explore other domains such a whole country's image to individual/personal image repair strategies (Len-Rios \& Benoit, 2004), individual (especially celebrities') crisis communication and political communication (Sheldon \& Sallot, 2008; Benoit, 2017). According to Stevenson (2009, p. 556), in the literature on organizational communication, "the specific situation framing the crisis communication and image repair has been discussed in terms of different audiences and stakeholders to which crisis responses should be adapted..., different types of crises requiring different communicative strategies..., and different cultures and systems of values".

Sheldon and Sallot (2008) state that research suggests that some of the strategies may not be applicable in politics, since politicians, corporate bodies and individual celebrities have key differences. Sheldon and Sallot argue that for politicians, openly accepting mistakes can be politically expensive. Benoit (1997, p. 256) admits that due to the potential litigation threats, politicians may be "less inclined than entertainers to use apology or mortification". This implies that which aspects of the theory of image repair are employed in communicating crisis depends on the context. In other words, individual and socio-cultural and political differences determine which aspects of the strategies are relevant for specific situations. This calls for more research from different contexts, making the current study significant. It explores the strategies employed by a former president of the Republic of Ghana to rationalise how and why he lost the 2016 presidential election in order to repair his tainted image.

Studies of how political leaders respond to criticisms of their character and policies (cf. Towner, 2009) predate Benoit's image repair theory. The theory has been explored through apologia (or self-defence) in the political context (Benoit, 1997; cf. Len-Rios \& Benoit, 2004), comprising negotiations of guilt, responsibility and social values, social standing and hierarchy, and of membership in a group, community, nation, or humankind (Towner, 2009).

Apologia has been considered as a rhetorical genre. For Abrahams (1968, p. 145), the full analysis of "genre calls 
for the study of organisational elements of both items and performances". In this paper, therefore, we are not only interested in studying the functional issues of defence and image repair, but also the rhetorical features which Mahama used in his speeches. Thus, we define rhetoric as "the use of symbolism and language to ensure that a message is encoded in the way desired by the communicator", as a way "to encourage a change in behaviour" (Lilleker, 2006, p. 182). We also include the three Aristotelian rhetorical proofs of ethos (appeal to the character, credibility or moral quality of the speaker), logos (appeal to logic or reason), and pathos (appeal to audience's emotions/feelings) (cf. Ilie, 2004; Charteris-Black, 2014). Rhetorical analysis helps to explore "the strategic deployment of shared linguistic resources in a context of contingently unfolding non-linguistic vents" (Walter, 2017, p. 300). It affords us the opportunity to examine how Mahama designed his language, such as the use of metaphor, for his purpose.

The forgoing indicates a strong connection among apologia, image repair and rhetoric. This study, therefore, makes use of an eclectic mix of theoretical approaches of apologia, image repair and rhetorical theories to measure the overall strategy employed by Mahama for the maintenance of his reputation after losing the 2016 elections while attempting to stage a comeback to contest the 2020 election as the standard bearer of the opposition NDC party. This study is significant because, in spite of the numerous studies on apologia, image repair and rhetoric, we are yet to see a single study that combines all the three theories. Combining the three in a study like the current one provides further insights into how these theories are intertwined and illuminate political discourse and communication. Again, notwithstanding the proliferation of studies on political figures and how they manage reputation, we are yet to see a study on a president who lost an election, attempted a comeback and, therefore, engaged in a multiple task of defence, image repair and campaign rhetoric.

\section{DATA AND METHOD OF ANALYSIS}

After losing the 2016 general elections, the National Democratic Congress (NDC) party organised a series of Unity Walks across the then ten (10) regions of Ghana in order to re-organise the grassroots of the Party to prepare for the 2020 general elections. At each of the Walks, John Mahama, the former President of Ghana, delivered a speech. The data for this study are transcripts of John Mahama's speeches delivered at the Unity Walks. Seven out of the 10 speeches were downloaded from YouTube (see the links listed after References), transcribed and analysed.

The study uses content analysis, "an analysis of the contents of a communication" (Fraenkel, Wallen \& Hyun, 2012, p. 502) in order to reveal, among others, the intentions, beliefs, attitudes, values, ideas and the psychological state of communicators (Weber, 1990). It is "the study of recorded human communications" that seeks to answer the question "Who says what, to whom, why, how, and with what purpose?" (Babbie, 2005, p. 328). The data analysis helped to respond to questions relating to the theoretical areas of apologia and image repair ("why", "with what purpose"?) and rhetoric ("how"?). The data were thematically coded to identify and examine instances of apologia and image repair strategies and rhetorical features that characterised the data. The following is a step-by-step description of how the data were processed and analysed.

i. We downloaded videos of the speeches from YouTube.

ii. We manually transcribed the speeches orthographically by watching and listening to the videos and speeches.

iii. We coded the speeches by the names of the towns where they were delivered.

iv. We read through the transcripts to identify instances of apologia, image repair strategies and rhetorical elements, and then analysed them.

\section{ANALYSIS AND DISCUSSION}

An examination of the data indicates that President Mahama did not accept responsibility for the 2016 electoral loss. The only time he came close to accepting responsibility was when he met with former appointees of his government in April 2017, and said: "Of course as the general who led us into battle, I take ultimate responsibility for our losing the election and so if it will satisfy those people, blame me for the loss" (Allotey, 2017, n.p). This is a conditional acceptance of responsibility, contingent upon the satisfaction of those who blamed him for the loss. Thus, throughout the Unity Walks, he found several ways to repair his image as being responsible for the electoral defeat. The analysis and discussion looks at the attempt from two main angles, namely: apologia and image repair (section 4.1), and the rhetorical tools employed (section 4.2).

\section{Apologia and Image Repair}

This section explores the ways in which President Mahama tried to defend himself as not being responsible for the NDC's loss of the 2016 elections and how he attempted to repair his image. We consider the organisation of the Unity Walks, Mahama's speeches and the rhetorical strategies as culminating in apologia. The strategies employed by Mahama included bolstering, accusation/attack, playing the victim, throwing a challenge and the "God's will" factor.

\section{Bolstering}

Bolstering is one of the ways of reducing the offensiveness of an act (Benoit, 1995; Len-Rios \& Benoit, 2004). It involves talking about ones positives (acclaim - cf. Benoit, 1999, 2017) and strengthening the offended through encouragement (Benoit, 1995). As a way of restoring his own image and that of the Party, the former President attempted to bolster his image and encourage party members by explaining to them the need for the Unity Walks, that is, to ensure solidarity among the members of the Party and "to raise the morale of the Party and to engage "party members so that they are conscious of the re-organization that is taking place" (NDC Unity Walk, Wa, Upper-West region, 07/04/2018). President Mahama made acclaims (cf. Benoit, 1999, 2017). According to Benoit (1999, 2017), in political campaign messages, politicians establish preferability 
through acclaim, that is, they talk about their positives so as to distinguish themselves from their opponents. Examples 1, 2 and 3 demonstrate how President Mahama made acclaims; he talks about some of the credible things he did as president.

Example 1 (Cape Coast, Central region, 05/11/2017):

When I was in office, there was a bus branding incident - 3.6 million Ghana cedis - a minister of state resigned because of 3.6 million Ghana cedis. In power, when you come into office and you want to cover up, you can cover up. When things happen, you just refuse to investigate them. The toughness of the fight against corruption is that you are able to take action against your own people, and that is what we did when we were in office.

Example 2(Bolgatanga, Upper-East region, 05/05/2018): When you offer any decisions, they call you all kinds of unprintable names. But I was not brought up to use unprintable names against my political opponents. The language you use in your political discourse is a reflection of your upbringing. If you were brought up well, it must reflect in the language that you use in your political discourse.

Example 3 (Wa, Upper-West region, 07/04/2018):

They will be there till $2021,7^{\text {th }}$ January and the people of this country will make a decision and that decision will be to tell the NDC we know you are the most capable managers of this country; it is you who bring us development; it is you who bring us infrastructure; it is you who make this country move forward and so by the grace of God, Insha Allah, the year 2020, NDC will win the election and the mandate of the people to come to power.

In Example 1, Mahama talks about how he was able to hold his own appointees accountable, viz: "The toughness of the fight against corruption is that you are able to take action against your own people, and that is what we did when we were in office". This is an appeal to ethics (ethos) (Ilie, 2004; Charteris-Black, 2014) aimed at rebuilding Mahama's credibility. In Example 2, he tells how he was brought up to use decorous language; while Example 3 is an encouragement to the members of the NDC to prepare to win the 2020 elections as the NDC is better at managing the economy than the NPP, stressing “ . . by the grace of God, Insha Allah, the year 2020, NDC will win the election and the mandate of the people to come to power". All these are indirect ways of telling the Party members that he was not responsible for the loss of the 2016 election, even though he does not mention what caused their defeat. By talking about his positives, Mahama attempts to debunk the impression that he was responsible for the NDC's defeat.

\section{Accusing, attacking the opponent}

The former President accused and attacked the then Opposition (the NPP, now in government) of embarking on a propagandist campaign and lies to deceive the people of Ghana to vote for them, and denunciates the government's inability to improve upon the living conditions of Ghanaians. Consider Examples 4 and 5.
Example 4 (Aflao, Volta region, 09/06/2018):

My brothers and sisters, in the run up to the election and since we lost, our opponents are master of lies and propaganda. Before the 2016 election, they subjected us to a barrage of propaganda based on lies and fabrication and even after we have lost, they have forgotten that they are now in power and that they must concentrate on governing and stop the propaganda and lies against the NDC party. Everyday, they cook up some stories to try and demonize the NDC as a party.

Example 5 (Kumasi, Ashanti region, 28/04/2018):

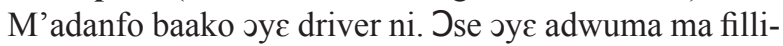

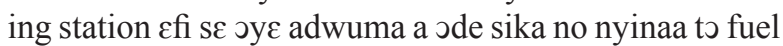

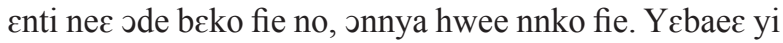
ara, maame bi ston waakye. Ose, oh, President Mahama, NDC abre so Waakye no meton 7 bowls everyday. Ose

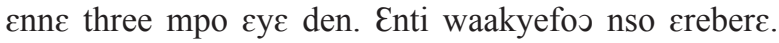

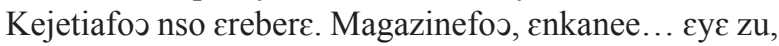

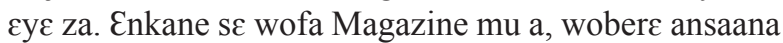
watumi afa mu. Na $\varepsilon n n \varepsilon$ de $\varepsilon$ wofa mu a, $\varepsilon$ te se woretwa paano.

(Translation: A friend of mine is a driver. He says he works for fuel stations because he uses all his money to buy fuel, so he gets nothing to take home. When we came here, there is a woman who sells Waakye (a local food). She says, "Oh, President Mahama, when the NDC was in power, I used to sell seven bowls of Waakye everyday. Today, it is difficult to sell even three bowls". So, Waakye sellers are suffering. The people of Kejetia are suffering. The Magazine people (local artisans), previously... cye zu, cye za (says NDC slogan). Previously, it was difficult to pass through Magazine. But today, when you go through, it is like cutting a piece of bread.)

Accusing the NPP of embarking on propaganda and lies is to indirectly debunk and discredit the NPP's 2016 electoral victory as genuinely based on reality and the facts at the time of the elections. It implies that if the NPP had based their campaign on the real state of affairs, they would not have won the election. Mahama suggests that he was not responsible for the electoral loss. Mahama further condemns the NPP government of worsening the living conditions of the people (see Example 5), saying that the people are suffering. To say that Ghanaians are suffering, using the businesses of drivers, Waakye sellers and the "Magazine" as examples, is to excite the emotions of the people, drawing on the persuasive principle of pathos (cf. Ilie, 2004; Charteris-Black, 2014).

Closely related to the accusations is "playing the victim" of unfair political discourse by the opponent. Consider Examples 6 and 7 .

\section{Playing the victim}

Playing the victim means blaming someone else for one's circumstances. It courts sympathy, manipulates a situation and people to one's advantage, as in:

Example 6(Bolgatanga, Upper-East region, 05/05/2018): When I was president, I was probably one of the most criticised and insulted president. 
Example 7 (Aflao, Volta region, 09/06/2018):

My brothers and sisters, sometimes, when I have listened to their lies, I feel very hurt in my heart at some of the creativity they have in crafting those lies. And sometimes you feel that it is easy for our country men to see that ah this is not true, this is a lie. But Goebbels' propaganda chief said that take a lie and tell it over and over and over again, and eventually, people will come to believe it is true. And so sometimes I feel very hurt and sometimes as human as I am, I feel like coming out and responding and retorting...

Here, the former President tries to avoid taking responsibility for losing the elections. He describes himself as a victim of propaganda, leading to the loss of the elections. Examples 6 and 7 contain emotions, as, for example, "when I have listened to their lies, I feel very hurt in my heart at some of the creativity they have in crafting those lies" and "And so sometimes I feel very hurt and sometimes as human as I am, I feel like coming out and responding and retorting...". He appeals to pity (pathos - cf. Ilie, 2004; Charteris-Black, 2014), as he plays on the emotions of the people. Playing victimhood in this sense is to imply that he was not responsible for what happened.

\section{Throwing a challenge}

Mahama threw a challenge to the NPP government to arrest and prosecute the appointees who were said to be corrupt during the Mahama administration, as considered in Example 8, which is in Twi, a Ghanaian language.

Example 8 (Kumasi, Ashanti region, 28/04/2018):

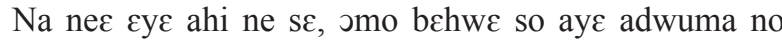
ama Ghana aye yie no ama ahokyere no ako famu no, dabiaa yesore a yese sika sei ayera. Na sika sei ayera a, $\mathrm{y} \varepsilon$ investigation na kyere nkrofo no $\varepsilon$. Wo ara na tumi no hye ne nsa. Naano yese TOR [Tema Oil Refinery], 150 billion is lost. How can 150 billion be lost? ena yen nyinaa daso enante Ghana abonten so? 150 billion ayera a kyere nkrofo a omo awia 150 billion no eh.

(Translation: What is irritating is that instead of them working to develop Ghana and reduce the suffering, every day, they are complaining that several sums of money are missing. If that money is missing, investigate it and arrest the people. You have the power. Recently, they said, at TOR, 150 billion is lost. How can 150 billion be lost? And we are still walking on the streets of Ghana? If 150 billion is missing, arrest those who stole it.)

One thing that became a major campaign issue in the round up to the 2016 elections was the problem of corruption. Mahama and his administration were labelled as corrupt, to the extent that Transparency International (2017: 3, see also Sarfo-Kantankah, 2018, p. 232) thought that the NDC lost the 2016 elections because of "rampant corruption". However, the NDC said that the Opposition was peddling a falsehood. To hammer home his government's innocence of corruption, Mahama challenges the NPP government to investigate, arrest and prosecute members of his government who engaged in corruption. This is a defensive mechanism aimed at proving his and his government's innocence. Mahama employs the artistic proof of logos (cf. Ilie, 2004; Charteris-Black, 2014 ) by quoting a figure (150 billion) to support his claim, that is, if " 150 billion is lost", then it is reasonable that those responsible are held accountable.

\section{The "God's will" factor}

Mahama sometimes attributed the loss of the 2016 elections to the will of God. Consider Example 9.

Example 9 (Aflao, Volta region, 09/06/2018):

I have always said that the Almighty God will speak. And if you look at the events of the last one and a half years, you can see that our God is a living God. Our God is a living God. The lies they told are unravelling in the war between truth and lies. Always, lies has an early victory but eventually the truth will always win. You can see that recent events are vindicating the NDC.

Mahama's claim that the NDC's defeat was sanctioned by God has been responded to by members of his own party, including flag-bearer hopefuls of the NDC, such as Ekow Spio-Garbrah, who is reported to have said: "God speaks to me, but he has not said that he orchestrated the party's defeat" (Ansah, 2018, n.p), asking Mahama not to bring God into his defeat (myjoyonline.com, 2018). Ghana is known to be a very religious country with about $71.2 \%$ of Ghanaians being Christians and $17.6 \%$ being Muslims (Ghana Statistical Service 2012). Many of the followers of these two religions believe in God's intervention in the making of leaders of a country. The interplay between religion and politics has long been acknowledged; and religion and the God factor is said to play a crucial role in politics, including the United States of American politics (see Lambert 2008, who traces the role of religion in American politics from the 1800s). Religion occupies a central role in American politics (Weber \& Thornton, 2012), to the extent that, in recent times, the Democrats are closing the God gap in their political inclination (Sullivan, 2008). In Ghana, there has been an increased focus on religion by politicians, especially, "since 2008 ... as a result of the strong relationship that Ghanaians have with their respective religions" (Boifio, 2014, p. 59). Thus, our political leaders and parties have always exploited the God factor to influence the electorate. It is not surprising, therefore, that Mahama plays the same religious card to justify the 2016 electoral defeat.

While the foregoing clearly demonstrates how Mahama tried to defend and justify the electoral defeat in 2016, an examination of the rhetorical strategies he employed in communicating his defence reveals an equally interesting phenomenon of how language can be used to effectively communicate one's ideas and feelings.

\section{Rhetorical Strategies}

Political discourse is characterised by rhetoric, the art of persuasion (cf. Charteris-Black, 2014), typified by "the use of symbolism and language to ensure that a message is encoded in the way desired by the communicator" (Lilleker, 2006, p. 182). Persuasion is achieved through the strategic use of language, including the use of rhetorical tools such as meta- 
phor, allusion, rhetorical questions and parallelism. Examining the rhetorical tools is important because the "proper usage of the tools of language, that is, rhetorical devices such as parallelism will enable the politician to capture the minds and interest of his audience" (Sarah, 2015, p. 35). Thus, in this section, we examine how Mahama used the above-mentioned rhetorical tools to achieve persuasion, an interactive communicative process aimed at influencing the beliefs, attitudes and behaviour of the audience (Jowett \& O'Donnell, 2006).

\section{Metaphor}

Metaphors, according to Taiwo (2013), are central to political discourse as they help to shape the structure of political categorisation and argumentation. The analysis of metaphor here is informed by Lakoff and Johnsen's $(1980,2003)$ conceptual metaphor, where metaphor is considered as understanding and experiencing one kind of thing in terms of another (Lakoff \& Johnsen, 2003, p. 5), that is, mapping one conceptual domain to another domain or regarding one thing as a symbol of another. Consider examples 10-15, which are metaphors used by Mahama. While Examples 10, 11 and 12 relate to accusations and attacks as discussed earlier (sub-section 4.1), Example 13 concerns Mahama's acclaim, and Examples 14 and 15 border on bolstering, that is, encouraging the NDC's re-organisation. Discussed below are: the metaphor of war between truth and lie, the metaphor of pay-as-you-go, the metaphor of football, the Metaphor of the honeymoon, the metaphor of roots and the metaphor of building blocks.

The metaphor of war between truth and lie. In Example 10 , by the concept of war, Mahama structures the relationship between truth and lying.

Example 10 (Aflao):

The lies they told are unravelling in the war between truth and lies. Always, lies has [have] an early victory but eventually the truth will always win.

This is similar to Lakoff and Johnsen's (2003) description of argument as war - which implies a verbal battle, attack, defence and counterattack. In politics, the issue of propaganda generates a lot of argumentation about which political groups are honest. Thus, the concept of war used by Mahama portrays truth finding as a long battle and struggle, even though eventually, there are winners and losers. And usually, it is the more powerful (in this instance, truth) who win the war. To say that "the lies they [the NPP] told are unravelling" implies that Mahama is trustworthy and that he will be exonerated as events unfold. It is a face-saving strategy. This amounts to attacking the opponent in order to establish credibility for oneself (cf. Benoit 1999, 2017).

The metaphor of pay-as-you-go. In example 11, Mahama describes the NPP government's governance, policy planning and implementation strategies as a mobile telephony (pay-as-you-go) deal.

Example 11 (Bolgatanga):

But there are many other things that this government is doing in an adhoc manner. It is as if they are governing in a manner called 'government as you go'. Because for every programme that is rolled up, there is no guideline and that is the problem - 'government as you go'.
A pay-as-you-go deal refers to a system where a person or an organisation pays for the cost of services as and when they are rendered without a contract. Thus, referring to the government as "government as you go" metaphorically depicts the NPP government as embarking on ad-hoc measures and policies, without plan. This is an attack on policy (cf. Benoit, 2017) and an indirect call for the change of the NPP government in the 2020 elections.

The metaphor of football. Example 12 (spoken in Fanti, a Ghanaian language) employs a football metaphor, in which spectators often give commentaries as though they were expert footballers, but when they are given the opportunity to play, they are found wanting.

Example 12 (Cape Coast):

Me kaa d $\varepsilon$ s $\varepsilon$ yereb football na wo tse nkyen a, wodwen $\mathrm{d} \varepsilon$ ball a worebo no ebotum appoint captain a วwว foot-

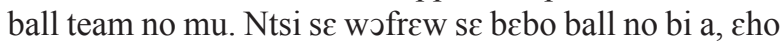
na ebohu wo smoothness level.

(Translation: I said that when they are playing a football match and you are watching it, you think that you can appoint the captain in the football team. But when you are called to play, you realise that you cannot play.)

This describes the NPP as being unable to execute their mandate as governors of the country, even though, in opposition, they touted their capability to run the affairs of the country. This reinforces the accusations and attacks Mahama makes against the NPP government.

The Metaphor of the honeymoon. In Example 13, Mahama compares the period $\left(7^{\text {th }}\right.$ January- $5^{\text {th }}$ November 2017) of the NPP government as a honeymoon period. It is a means of portraying himself as a reasonable, thoughtful person who abhors opposition for its sake.

Example 13 (Cape Coast):

I have refrained from commenting on national issues because I think that when the new government comes into power, you should give it a honeymoon so that it can settle in.

Allowing a government a free period without criticising it indicates a rational person. This is an attempt at justifying his criticisms against the government and making the criticisms credible, after all, the honeymoon is over. As noted by Palmatier (2000, p. 182)

the honeymoon metaphor has been extended in modern times to the relationship between a newly elected official, such as the president of the United States, and the loyal opposition with whom he/she must deal. It has become a custom to give the president a 'break' from opposition during his/her first few months in office - i.e., a honeymoon.

The period of the honeymoon implies ceasing all opposition criticisms and censure, such as Mahama having "refrained from commenting on national issues", in order to allow the government to settle down, plan and implement its policies. It is aimed at enhancing Mahama's credibility (ethos - an appeal to the character of the speaker (cf. Ilie, 2004; Charteris-Black, 2014)).

The metaphor of roots. Example 14 metaphorically structures the Branches ${ }^{1}$ of the NDC as roots (the Branches are roots). 


\section{Example 14 (Wa):}

If the branches are strong, the party is strong because the branches are actually the root of the party - they hold the party up. If a tree does not have strong roots and the wind blows, it can blow the tree down.

Roots are a metaphor for strong support to hold the Party together; to be fruitful, the tree needs strong roots. Thus, the NDC needs strong support from the Branches to be united, strong and successful in its attempt to recapture power. The overall aim is to encourage unity and strength within the Party. The same concept is echoed in Example 15, the metaphor of building blocks.

The metaphor of building blocks (cf. Lakoff \& Johnsen, 2003) is used to structure the concept of unity and peace. This means that unity and peace need to be constructed like a building.

\section{Example 15 (Aflao):}

You need building blocks to work towards the achievement of unity and peace. And these unity walks have just been one of those building blocks.

Mahama sees peace building as methodical, a conscious attempt in which small parts are assembled to achieve a complete whole, suggesting the challenges involved in building peace and unity. Thus, Mahama implies that the NDC need to reconcile their differences to, in his words, "re-uniting our party and putting it in a position to fight the next elections".

The use of metaphors allows Mahama to give a symbolic and picturesque view of the current and future state of the NDC; it hammers home the real concerns of the Party. Consequently, we do agree with Charteris-Black (2004, p. 247) that "metaphor selection in particular types of discourse is governed by the rhetorical aim of persuasion". Mahama's purpose in the speeches was mainly persuasive, as he aimed at convincing, stimulating, motivating and influencing the beliefs and attitudes of the members of the NDC.

\section{Allusion}

Mahama alluded to George Orwell's Animal Farm to describe the NPP government as practising politics of discrimination, after having deceived Ghanaians that, if they (NPP) won power, "there shall be no discrimination" on any grounds but they are now practising Animal Farm politics: "all animals are equal but some are more equal than others".

Example 16 (Cape Coast):

... the constitution of Ghana says there shall be no discrimination, and that you shall do justice to all manner of people, that is what the constitution of Ghana says. Then you come and say ... have you read Animal Farm before? It says all animals are equal; that is how they started. When they did the revolution, they said all animals are equal. Then when Napoleon and the pigs started enjoying, they had to justify why they were enjoying so they said all animals are equal but some are more equal than others.

This is an allusion (an indirect reference to someone or something) to a literary text which conveys a strong political underpinning. Animal Farm is a fable that tells the story of the animals of a farm revolting against their human own- er and overthrowing him for being cruel to them, and ruled by their own kind only to slither into a more brutal tyranny. Mahama suggests that the people of Ghana voted against the NDC government based on complaints of hardship and discrimination only to slide into a more serious hardship and discrimination under the NPP administration. The reference to Animal Farm is a logical appeal (logos) (cf. Ilie, 2004; Charteris-Black, 2014) intended to make the audience draw equivalences between Animal Farm and their situation in order to recognise the mistake they made in voting for the NPP. Similarly, the reference to the "constitution of Ghana" is a logical appeal aimed at making the audience realise that their constitutional rights are being trampled upon.

\section{Rhetorical questions}

Rhetorical questions (RQs) are "questions that are not meant to be answered, but rather to convey a message that would not be as memorable and as persuasive had it been expressed as a straightforward statement" (Špago, 2016, p. 103). They are a way of asserting a point by means of a question. Consider the italicised questions in Examples 17, 18 and 19. Often, the questioner answers the question him-/her-self, as in Example 17: "They are also cutting swords again for projects that we had cut sword for already".

Example 17 (Volta):

Those projects that they described as photo shop, they are going round and commissioning them today. But you know the most shocking? They are also cutting swords again for projects that we had cut sword for already.

Example 18 (Volta):

They cannot even give credit where it is due. What does it take away from you if you give credit? President Rawlings carried out the feasibility study for the Bui Dam project. President Kufuor came and found the money and started the project. When President Mills came, the money President Kufuor found was not enough so President Mills went to China and got them to give us additional money. The project was finally finished under President Mahama. When I went to commission the Bui Dam project, I invited President Kufuor to come and sit down and I told the whole country. I said this man started this project. What do you lose? When President Mills was commissioning the N1 project, he invited President Kufuor to come and sit down ... [because] it is President Kufuor who started it. What do you lose? It shows the pettiness, low standards, immaturity of NPP as a government.

Example 19 (Bolgatanga):

When we were in government, they said oh the size of the government is too high; you must reduce the size of government. Then when they come into government and they appoint 110 ministers, 909 presidential staffers, then they say oh, it is not about quantity; it is about quality. Who determines quality? You know, when they are (...) family and friends, so it is a family and friends government. Then when they come into government, they appoint all their relatives into government and when you talk, they say oh, it doesn't matter but it is 
whether they are qualified. Who doesn't have relatives who are qualified? We have many relatives who are qualified who could have helped in my government.

According to Špago (2016, p. 103), RQs are widely used in different languages and contexts, including politics and communication "[d]ue to their persuasive effect and communicative effectiveness". RQs are mental-response questions (Ilie, 1994), and, therefore, their use indirectly encourages audience's cognitive engagement and involvement in a discourse, thereby strengthening the memorability of the message. Ilie (1994, p. 128) sees RQs as “... a question used as a challenging statement to convey the addresser's commitment to its implicit answer, in order to induce the addressee's mental recognition of its obviousness and the acceptance, verbalized or non-verbalized, of its validity". In Example 18 , the response to the questions is obvious: you do not lose anything. This unspoken response is emphasised by the examples given by Mahama to illustrate how other Presidents invited their predecessors to the inauguration of projects initiated by those predecessors. In Example 19, Who determines quality? rhetorically elicits the response nobody, emphasising the subjectivity of what quality means. Again, it is obvious that every president has relatives whom they can appoint into offices. All the RQs used by Mahama are meant to highlight what he sees as "the pettiness, low standards, immaturity of NPP as a government", which indirectly projects Mahama as critical, important, mature and trustworthy - an image repairing strategy. Thus, rhetorical questions can be used to advance, reinforce or reject a belief, an assumption or an opinion and manipulate the audience (Ilie, 1994).

\section{Parallelism}

Parallelism refers to the expression of several ideas in a series of similar or the same or equivalent grammatical form/ structure, for example, words and words, phrases and phrases or clauses and clauses (cf. Al-Ameedi \& Mukhef, 2017). According to Johnstone (1991, p. 33) "[t]o say that two linguistic structures are parallel is to say that they share a common structural frame, and that within this frame, some element or elements differ in form" even though "the elements that differ always stand in close relationship to one another", as illustrated by Example 20. While the first, the third and the last structures have the form: Subject + Verb + Object, the other three have the form: Subject + Verb + Complement.

Example 20 (Aflao, Volta):

Our opponents (Subject) accused (Verb) us (Object) of incompetence and these same opponents (Subject) are displaying (Verb) the most crux super incompetence ever witnessed in the history of Ghana (Object).

Our opponents who accused us of being corrupt (Subject) are proving (Verb) in government to be - and using Manesseh Azuri's words - 'sophisticated eves' (Complement).

Our opponents who accused us of subjecting Ghanaians to hardship (Subject) are putting (Verb) Ghanaians through the most severe hardship ever experienced in Ghana's history (Object).
Our opponents who accused us without any evidence of running a family and friends' government (Subject) are proving (Verb) to be the most nepotic government ever in the history of Ghana (Complement).

Our opponents who accused us of excessive borrowing (Subject) are proving (Verb) to be the government that has borrowed at the fastest rate ever in the history of Ghana. (Complement).

Our opponents who accused us of photo shop projects (Subject)... are going round and commissioning (Verb) those photo shop projects (Object).

Parallelism provides rhetorical emphasis to improve the understanding and the memorability of an idea in a more forceful manner, by drawing attention to a particular part of the message and making it stand out (Al-Ameedi \& Mukhef, 2017). The criticism and the persuasive power contained in the above parallel structures are intensified by the idea of $X$ yet $Y$, a contrastive pair or an antithesis, consisting of two parts in opposition (Sarah, 2015). Here, Mahama creates a sense of surprise between what the NPP criticised and what they are practising, that is, preaching virtue but practising vice. The parallel structures make the criticism espoused by Mahama "more concrete, vivid and telling" (Iványi, 1993, p. 50) thereby aiding memorability of the message just as rhetorical questions do (cf. Ilie, 1994). The persuasive power of the parallel structures is heightened by the repetition of our opponent. The repetition gives the message an emotional emphasis (cf. Johnstone, 1994) and adds to the persuasiveness of the message.

The rhetorical tools discussed above were designed to boost the image repair strategies employed by Mahama to deny responsibility for the 2016 electoral loss. Mahama used the rhetorical devices to concretise his message and make it vivid in order to enhance its believability. By using those devices, Mahama was able to create a picturesque view of his accusations and attacks, his credibility and the unity, reinforcement and strength needed by the NDC to reorganise itself to face the 2020 elections. In short, the rhetorical tools helped to sharpen Mahama's rhetorical appeals.

\section{CONCLUSION}

Based on the concepts of apologia, image repair and rhetoric, this paper sought to examine how John Mahama, a former President of Ghana, through his speeches at the National Democratic Congress (NDC) party's Unity Walks, attempted to discredit the claim that he was responsible for the NDC's 2016 electoral defeat, while trying to regain a credible reputation and prepare the grounds for his comeback to contest the 2020 presidential elections as the standard bearer of the NDC. The findings of the paper indicate that the former president did not accept responsibility for the electoral loss. He employed numerous indirect ways to deny responsibility for the defeat. Mahama evaded responsibility by engaging in bolstering, accusation/attack, playing the victim, throwing a challenge, and the God's will factor as defence strategies in order to repair his image. Mahama accused the New Patriotic Party (NPP) of embarking on a propagandist campaign and insults, such as he and his government being tagged as corrupt, to manipulate 
Ghanaians to vote against the NDC; Mahama played the victim. By way of proving his and his government's innocence of corruption, Mahama threw a challenge to the NPP government to arrest and prosecute all those who were thought to be corrupt. Mahama also described the defeat as being God's will, because God wanted Ghanaians to experience the deeds of the NDC's administration and those of the NPP's administration so that they could judge for themselves which of the two had the requisite credibility to govern Ghana. Mahama utilised the Aristotelian appeals of logos, ethos and pathos to boost his persuasion. Again, to enhance the persuasiveness of his defence strategies, Mahama deployed several rhetorical tools such as metaphor, allusion, rhetorical questions and parallelism. The analysis further reveals that, as noted in the literature (cf. Benoit, 1997; Sheldon \& Sallot, 2008), some of the image repair strategies espoused by Benoit $(1995,2015)$, for example, outright denial and mortification, hardly apply to (certain) political contexts - Mahama's defence was indirectly expressed. The paper concludes that combining the concepts of apologia, image repair and rhetoric in the analysis of political discourse can illuminate the study of political discourse analysis and offer a comprehensive understanding of communicating defence and image repair.

\section{ACKNOWLEDGEMENT}

I wish to acknowledge Mr Frank Mensah, a teaching assistant at the Department of English, University of Cape Coast, for his assistance in the transcription of the data.

\section{END NOTE}

1. Units of the Party at the grassroots

\section{REFERENCES}

Abrahams, R.S. (1968). Introductory remark to a rhetorical theory of folklore. Journal of American Folklore, 81(320), 143-158.

Achter, P.J. (2000). Narrative, intertextuality, and apologia in contemporary political scandals. Southern Journal of Communication, 65(4), 318-333. DOI: 10.1080/10417940009373179

Al-Ameedi, R.T. \& Mukhef, R.N. (2017). Aspects of political language and parallelism. Journal of Education and Practice, 8(34), 185-200.

Allotey G.A. (2017). Blame me for NDC's defeat in 2016 - Mahama. [Online]. Available: http://citifmonline. com/2017/04/12/blame-me-for-ndes-defeat-in-2016mahama

Ansah, M. (2018). God hasn't told me he caused NDC's defeat - Spio Garbrah. [Online] Available: https://citinewsroom.com/2018/09/28/god-hasnt-told-me-hecaused-ndcs- defeat-spio-garbrah

Babbie, E. (2005). The basics of social research. ( $3^{\text {rd }}$ ed.). USA: Thomson Wadsworth.

Benoit, W.L. (1995). Accounts, excuses, and apologies: a theory of image restoration strategies. Albany: State University of New York Press.
Benoit, W.L. (1997). Hugh Grant's image restoration discourse: an actor apologises. Communication Quarterly, 45(3), 251-267. DOI: 10.1080/01463379709370064

Benoit, W.L. (1999). Seeing spots: a functional analysis of presidential television advertisements, 1952-1996. Westport, CT: Praeger Publishers.

Benoit, W.L. 2000. Another visit to the theory of image restoration strategies. Communication Quarterly, 48, 40- 44.

Benoit, W.L. (2004). Image restoration discourse and crisis communication. In D. P. Millar, \& R. L. Heath (Eds.), Responding to crisis: a rhetorical approach to crisis communication (pp. 263-280). Mahwah, NJ: Lawrence Erlbaum Associates.

Benoit, W.L. (2017). Meta-analysis of research on the functional theory of political campaign discourse. Speaker and Gavel, 54(1), 7-50.

Boifio, J.N.A. (2014). "The battle is the Lord's": Religion as a tool for political branding in Ghana's fourth republic. BA thesis, Ashesi University College, Ghana.

Boyer, A.R. (2011). Lifting "the long shadow": kategoria and apologia in the Legacy of the Tuskegee Syphilis Study. PhD thesis, University of Pittsburgh.

Charteris-Black, J. (2004). Corpus approaches to critical metaphor analysis. Basingstoke/New York, NY: Palgrave-Macmillan.

Charteris-Black, J. (2014). Analysing political speeches: Rhetoric, discourse and metaphor. UK: Palgrave Macmillan.

Fraenkel, J.R., Wallen, N.E. \& Hyun, H.H. (2012). How to design and evaluate research in education ( $\left.8^{\text {th }} \mathrm{ed}.\right)$. New York: McGraw-Hill.

Ghana Statistical Service 2012. 2010 population and housing census: summary report. Accra: Sakoa Press.

Ilie, C. (1994). What else can I tell you? A pragmatic study of English rhetorical questions as discursive and argumentative acts. Stockholm: Almqvist and Wiksell International.

Ilie, C. (2004). Insulting as (un)parliamentary practice in the British and Swedish parliaments: a rhetorical approach. In P. Bayley (Ed.), Cross-cultural perspectives on parliamentary discourse (pp.45-86). Amsterdam: John Benjamins.

Iványi, T. (1993). Dynamic vs. static - a type of lexical parallelism in al-Hamad̄ān̄̄'s Maqāmāt. In K. Devenyi, T. Iványi, and A. Shivtiel. The Arabist (Eds.), Proceedings of colloquium on Arabic Lexicography and Lexicography (49-58). Budapest, Hungary, 1-7 September 1993.

Johnstone, B. (1991). Repetition in Arabic discourse: Paradigms, systems, and the ecology of language. Amsterdam/Philadelphia: John Benjamins.

Johnstone, B. et al. (1994). Repetition in discourse: a dialogue. In B. Johnstone (Ed.), Repetition in discourse: Interdisciplinary perspectives (Vol 1, pp.1-20). Norwood, N.J.: Ablex Publishing Corporation.

Jowett, G. \& O’Donnell, V. (2006). Propaganda and persuasion ( $4^{\text {th }}$ ed.). Thousand Oaks/London: Sage Publications

Kruse, N.W. (1981). The scope of apologetic discourse: establishing generic parameters. Southern Speech Communication Journal, 46, 278-291. 
Lakoff, G. \& Johnson, M. (1980). Metaphors We Live By. Chicago: University of Chicago Press.

Lakoff, G. \& Johnsen, M. (2003). Metaphors we live by. London: The University of Chicago Press.

Lambert, F. (2008). Religion in American politics: a short history. United Kingdom: Princeton University Press.

Len-Rios, M.E. \& Benoit, W.L. (2004). Gary Condit's image repair strategies: determined denial and differentiation. Public Relations Review, 30, 95-106.

Myjoyonline.com (2018). Don't bring God into your defeat, you caused it - Spio-Garbrah to Mahama. [Online] Available: https://www.myjoyonline.com/politics/2018/ September-28th/dont-bring-god-into-your- defeat-youcaused-it-spio-garbrah-to-mahama.php

Palmatier, R.A. (2000). A dictionary of literal and nonliteral terms. London: Greenwood Press.

Roland, R.C. \& Jerome, A.M. (2004). On organisational apologia: a reconceptualization. Communication Theory, 14(3), 191-211.

Sarah, B. (2015). A stylistic study of parallelism in the presidential speeches of presidents Barack Obama and Goodluck Jonathan. MA thesis, Amadu Bello University, Nigeria.

Sarfo-Kantankah, K.S. (2018). Corruption is a big issue: a corpus-assisted study of the discursive construction of corruption in Ghanaian parliamentary discourse. Legon Journal of the Humanities, 29(1), 226-258.

Sheldon, C.A. \& Sallot, L.M. (2008). Image repair in politics: testing effects of communication strategy and performance history in a faux pas, Journal of Public Relations Research, 21(1), 25-50. DOI:10.1080/10627260802520496

Špago, D. (2016). Rhetorical questions or rhetorical uses of questions? ExELL (Explorations in English Language and Linguistics), 4(2), 102-115. DOI: 10.1515/ exell-2017-0009

Stevenson, P. (2009). Embracing left and right image repair and crisis communication in a polarized ideological milieu. Management communication Quarterly, 22(4), 555-576.

Sullivan, A. (2008). The party faithful: how and why Democrats are closing the God gap. New York, NY: Scribner.

Taiwo, R. (2013). Metaphors in Nigerian political discourse. In N-L, Johannesson \& D.C. Minugh (Eds.), Select- ed papers from the 2008 Stockholm metaphor festival (pp. 193-205). Stockholm: Stockholm University.

Towner, E.B. (2009). Apologia, image repair, and reconciliation: the application, limitations, and future directions of apologetic rhetoric. Annals of the International Communication Association, 33(1), 431-468. DOI: 10.1080/23808985.2009.11679093

Walter, R. (2017). Rhetoric or deliberation? The case for rhetorical political analysis. Political Studies, 65(2), 300-315.

Ware, L.B. \& Linkugel, W.A. (1973). They spoke in defense of themselves: on the generic criticism of apologia, Quarterly Journal of Speech, 59(3), 273- 28 3. DOI:10.1080/00335637309383176

Weber, C. \& Thornton, M. (2012). Courting Christians: how political candidates prime religious considerations in campaign ads. The Journal of Politics, 74(2), 400-413. http://dx.doi.org/10.1017/S0022381611001617

Weber, R.P. (1990). Basic Content analysis. (2 $2^{\text {nd }}$ ed.). London: Sage Publications.

\section{Data Links}

1. https://www.primenewsghana.com/politics/photosjohn-mahama-leads-final-ndc-unity-walk-in-afloa.html (Mahama at NDC Unity Walk at Aflao, Volta region, 9 June 2018)

2. https://www.youtube.com/watch? $\mathrm{v}=\mathrm{UqJMg}$ MrSfNI (Mahama at NDC Unity Walk in Kumasi, Ashanti region, 28 April 2018)

3. https://www.youtube.com/watch?v=q3LoT6Q0u0M (Mahama at NDC Unity Walk in Wa, Upper-West region, 7 April 2018)

4. https://www.youtube.com/watch? $\mathrm{v}=\mathrm{DN} 19$ tsLlVA (Mahama at NDC Unity Walk at Bolgatanga, Upper-East region, 5 May 2018)

5. https://youtu.be/aELFCWUwrGQ (Mahama at NDC Unity Walk at Tarkwa, Western region, 25 November 2017)

6. https://youtu.be/NIMFnjRzfXk (Mahama at NDC Unity Walk in Cape Coast, Central region, 5 November, 2017)

7. https://youtu.be/4pKw-TTiVWY (Mahama at NDC Unity Walk in Techiman, Brong-Ahafo region, 6 January 2018) 